\title{
NATIVE PRAIRIE AND BIODIVERSITY IN SASKATCHEWAN
}

SCOTT WILSON, Department of Biology, University of Regina, Regina, Saskatchewan. S4S OA2

Native prairie is essential to the conservation of biodiversity and Saskatchewan has an important role to play in the conservation of global biodiversity through the conservation of its prairies. In spite of this, native prairie in Saskatchewan is lost every year to cultivation, roadside improvement and wildlife habitat management.

There are several scientific definitions of diversity, but a simple, practical definition is simply the number of species present in an area.

The mixed-grass prairie of Saskatchewan appears to have low diversity, compared to a tropical rainforest or a coral reef. I suggest that this is a matter of scaling. If humans were the size of grasshoppers, the prairie would look pretty diverse.

First, there are many kinds of grass in native prairie: tussock grasses (e.g., spear grass) and sod grasses (e.g., grama grass), cool season grasses (e.g., junegrass) and warm season grasses (e.g., little bluestem). ${ }^{8}$ One of the commonest "grasses" isn't a grass at all, but a sedge. ${ }^{7}$ Then there are many, many wildflowers. ${ }^{12}$ Several of these are nitrogen fixers. There are shrubs such as creeping juniper and prairie rose. In dry areas, most of the biomass is composed of lichens and clubmosses (Selaginella). ${ }^{13}$ Lastly, a tablespoon of prairie soil can contain over $1,000,000$ algae cells, not to mention fungi. ${ }^{6}$ So there is a lot more to prairie plant diversity than just grass.

All this plant diversity directly affects the diversity of insects, mammals and birds. A very rough rule of thumb is that there may be four species of herbivores and carnivores for every species of plant. ${ }^{4}$ One native prairie can hold 309 vascular plants, and thus, many animal species. Many of the insect species have not yet been named. ${ }^{2,10}$

Fire has no effect on the diversity of mixed-grass prairie, in contrast to tall-grass prairie where fire may increase diversity. ${ }^{11,16}$ If used to remove invading shrubs, however, fire also increases diversity in mixedgrass prairie. ${ }^{1}$

Heavy grazing results in the loss of native prairie species. They may be replaced by European weeds, so the total diversity does not change. ${ }^{3}$ This example shows, surprisingly, that diversity alone must not be used as a single criterion for the conservation of biodiversity. The biodiversity value of a plot with 30 native species on it is much greater than a plot with 30 weeds on it, because the weeds have been spread to many parts of the world (Europe, Asia, Australia, Africa, South America) whereas the native plants are found only on the Great Plains of North America. Thus, Saskatchewan has an important role to play in the conservation of global biodiversity.

Cultivation, of course, results in 
the loss of native prairie and its biodiversity. Land that is abandoned from cultivation will continue to sustain low diversity. It may be planted to brome grass or crested wheatgrass, or it may be invaded by an European perennial such as leafy spurge. ${ }^{5}$ Either of these events results in the loss of both plant and bird diversity. ${ }^{14,15}$ The widespread replacement of native prairie along roadsides and in wildlife management areas with European species has a similar effect.

Native prairie may not return to land that has been cultivated for a few years, due to the extermination of both prairie plants and their seeds. Only half of the fields near Swift Current abandoned from cultivation for 40 years contained some native plants. ${ }^{9}$ The density of natives was extremely low: $95 \%$ of the plants were European.

Native prairie is very diverse compared to cultivated land or tame grass pasture. Native prairie is important to the conservation of global biodiversity. This diversity begins with the plants, but extends down to the soil microbes and up to the largest mammals and birds. It needs protection in Saskatchewan.

1. ANDERSON, H.G., and A.W. BAILEY. 1980. Effects of annual burning on grassland in the aspen parkland of east-central Alberta. Ca. nadian Journal of Botany 58:985-996.

2. BARNES, P.W., L.L. TIESZEN, and D.J. ODE. 1983. Distribution, production, and diversity of $\mathrm{C} 3$ - and C4dominated communities in a mixedgrass prairie. Canadian Journal of Botany 61:741-751.

3. BEEBE, J.D., and G.R. HOFFMAN. 1968. Effects of grazing on vegetation and soils in southeastern South Dakota. American Midland Naturalist 80:96-110.

4. BEGON, M.M., J.L. HARPER, and
C.R. TOWNSEND. 1990. Ecology: individuals, populations and communities. Blackwell Scientific Publications, Boston. 945 pp.

5. BELCHER, J.W., and S.D. WILSON. 1989. Leafy spurge (Euphorbia esula L.) and the species composition of mixed-grass prairie. Journal of Range Management 42:171-175.

6. COUPLAND, R.T. 1973. Algae and moss populations in soil. Technical Report No. 23, Matador Project, Saskatoon. $31 \mathrm{pp}$.

7. HUDSON, J.H. 1977. Carex in Saskatchewan. Bison, Saskato on. 193 $\mathrm{pp}$.

8. LOOMAN, J. 1982. Prairie grasses identified and described by vege tative characteristics. Agriculture Canada, Ottawa. 244 pp.

9. LOOMAN, P.E., and D.H. HEINRICHS. 1973. Stability of crested wheatgrass pastures under long-term pasture use. Canadian Journal of Plant Science 53:501-506.

10. MAY, R.M. 1988. How many species are the re on earth? Science 241:1441-1449.

11. RICE, E.L., and R.L. PARENTI. 1978. Causes of decreases in productivity in undisturbed tall grass prairie. American Journal of Botany 65:1091-1097.

12. VANCE, F.R., J.R. JOWSEY, and J.S. MCLEAN. 1984. Wildflowers across the prairies. Western Producer Prairie Books, Saskatoon. 336 pp.

13. VITT, D.H., J.E. MARSH, and R.B. BOVEY. 1988. Mosses, lichens and ferns of northwest North America. Lone Pine Publishing, Edmonton. 296 $\mathrm{pp}$.

14. WILSON, S.D. 1988. The suppression of native prairie by alien species introduced for revegetation. Landscape and Urban Planning 17:1 13-119.

15. WILSON, S.D., and J.W. BELCHER 1989. Plant and bird communities of native prairie and introduced Eurasian vegetation in Manitoba, Canada. Conservation Biology 3:39-44.

16. WILSON, S.D., and J.M. SHAY. 1990. Competition, fire and nutrients in a mixed-grass prairie. Ecology 71:19591967. 